\title{
Determination of Catecholamines in Pharmaceutical Formulations Using a Biosensor Modified with a Crude Extract of Fungi Laccase (Pleurotus ostreatus)
}

\author{
Oldair D. Leite ${ }^{a}$, Orlando Fatibello-Filho ${ }^{*, a}$ and Aneli de M. Barbosa ${ }^{b}$ \\ ${ }^{a}$ Departamento de Química, Universidade Federal de São Carlos, Rod. Washington Luiz, km 235, \\ 13560-970 São Carlos-SP, Brazil \\ ${ }^{b}$ Departamento de Bioquímica, Universidade Estadual de Londrina, Campos Universitário, 85051-990 \\ Londrina-PR, Brazil
}

\begin{abstract}
Um biossensor de pasta de carbono modificado com extrato bruto enzimático do fungo Pleurotus ostreatus como fonte de lacase é proposto para a determinação de catecolaminas em formulações farmacêuticas. Essa enzima catalisa a oxidação de adrenalina ou dopamina nas quinonas correspondentes e a corrente obtida na redução eletroquímica de cada um dos produtos é relacionada a concentração dessas catecolaminas em solução da amostra. $O$ efeito da concentração de lacase de 0,29 a 1,8 U/mg de pasta de carbono, do $\mathrm{pH}$ de 3,0 a 8,0, da velocidade de varredura de 10 a $40 \mathrm{mV} \mathrm{s}$ ${ }^{1}$ e amplitudes de pulso de potencial de 10 a $60 \mathrm{mV}$ sobre a resposta voltamétrica de pulso diferencial foi investigado. $\mathrm{O}$ desvio padrão relativo foi menor que $1,8 \%$ para solução de hidroquinona $2,8 \times 10$ ${ }^{4} \mathrm{~mol} \mathrm{~L}{ }^{-1} \mathrm{em} \mathrm{pH} 7$ (n=10). Recuperações variando de 97,3 a $101 \%$ para adrenalina e de 95,8 a $102 \%$ para dopamina foram obtidas. As curvas analíticas foram lineares no intervalo de concentração de adrenalina de $6,0 \times 10^{-5}$ a $7,0 \times 10^{-4} \mathrm{~mol} \mathrm{~L}^{-1}$ e de $7,0 \times 10^{-5}$ a $4,0 \times 10^{-4} \mathrm{~mol} \mathrm{~L}^{-1}$ para dopamina, com limites de detecção de 7,9 x $10^{-6} \mathrm{~mol} \mathrm{~L}^{-1}$ e $9,8 \times 10^{-6} \mathrm{~mol} \mathrm{~L}^{-1}$, respectivamente. Esse biossensor foi empregado para a determinação de adrenalina e dopamina em formulações farmacêuticas. Os resultados obtidos com o biossensor para a determinação dessas catecolaminas em formulações farmacêuticas estão em concordância a um nível de confiança de $95 \%$ com o procedimento da Farmacopéia americana.
\end{abstract}

A carbon paste biosensor modified with a crude enzymatic extract of the Pleurotus ostreatus fungi as a laccase source is proposed for catecholamine determination in pharmaceutical formulations. This enzyme catalyzes the oxidation of adrenaline or dopamine in the corresponding quinones and the current obtained in the electrochemical reduction of each of the products is related to the concentration of these catecholamines in the sample solution. The effect of the laccase concentration from 0.29 to $1.8 \mathrm{U} / \mathrm{mg}$ of carbon paste, $\mathrm{pH}$ from 3.0 to 8.0 , scan rate from 10 to $40 \mathrm{mV} \mathrm{s}^{-1}$ and potential pulse amplitude from 10 to $60 \mathrm{mV}$ on the differential pulse voltammetric response was investigated. The relative standard deviation was smaller than $1.8 \%$ for a $2.8 \times 10^{-4} \mathrm{~mol} \mathrm{~L}^{-1}$ hydroquinone solution at $\mathrm{pH} 7.0(\mathrm{n}=10)$. Recoveries varied from 97.3 to $101 \%$ for adrenaline and from 95.8 to $102 \%$ for dopamine. The analytical curves were rectilinear in the adrenaline concentration range from $6.0 \times 10^{-5}$ to $7.0 \times 10^{-4} \mathrm{~mol} \mathrm{~L}^{-1}$ and $7.0 \times 10^{-5}$ to $4.0 \times 10^{-4} \mathrm{~mol} \mathrm{~L}^{-1}$ for dopamine, with detection limits of $7.9 \times 10^{-6} \mathrm{~mol} \mathrm{~L}^{-1}$ and $9.8 \times 10^{-6} \mathrm{~mol} \mathrm{~L}^{-1}$, respectively. This biosensor was used for adrenaline and dopamine determinations in pharmaceutical formulations. The results obtained using the proposed biosensor are in close agreement with those obtained using an American Pharmacopoeia procedure at a $95 \%$ confidence level.

Keywords: laccase, Pleurotus ostreatus, catecholamines, biosensor

\section{Introduction}

Catecholamines play an important role in the central nervous system as neurotransmitters. They also affect the

* e-mail: bello@dq.ufscar.br regulation of blood pressure and metabolic processes. ${ }^{1}$ They possess important intrinsic pharmacological properties and are used for the correction of hemodynamic disorders associated with shock episodes. ${ }^{2}$

The determination of catecholamines in biological fluids normally requires the use of trace analysis techniques, 
mainly chromatography with fluorimetric or electrochemical detection. ${ }^{3}$ On the other hand, catecholamines are present in relatively larger amounts in pharmaceuticals and much effort has been done to develop precise, accurate, rapid and simple analytical procedures. ${ }^{4,5}$ Electroanalytical techniques applied to the determination of catecholamines are good alternatives. ${ }^{6-9}$ Nevertheless, the selectivity can be poor, unless the electrodes are conveniently modified. Thus, the use of enzymes has received a great deal of attention.

During the past few years there has been great interest in the study of enzymatic electrodes, related to applications. ${ }^{10}$ In addition to purified enzymes,,${ }^{11-13}$ animal, ${ }^{14}$ and vegetable extracts, ${ }^{15-18}$ immobilized on the electrode surface by different methods, have also been employed as catalyst sources in both aqueous and organic solutions. Carbon paste electrodes have been widely used owing to the possibility of immobilizing not only enzymes, but also ligands, redox mediators, biological tissues, to catalyze the oxidation/reduction of compounds involved in enzymatic reaction. The low-cost and ease of surface renewal are other important advantages..$^{19,20}$

The edible mushroon Pleurotus ostreatus, a white-rot fungus cultivated in submerged culture, has been found to produce laccase, a copper-containing polyphenol oxidase. Laccase (EC 1.10.3.2), catalyses the oxidation of various aromatic compounds (di- and polyphenols, aminophenols and diamines) by reducing molecular oxygen to water through an oxidoreductive multicopper system. ${ }^{21}$ These oxidases are involved in biotransformation and bioremediation processes, they can be also used in molecular genetics, ${ }^{22}$ genetic expression, ${ }^{23}$ genetic transcription ${ }^{24}$ and cloning. ${ }^{25}$ Consequently, laccases from white-rot fungi such as Pleurotus ostreatus are good candidates for further investigation, as they have potential in biosensor applications. Thus, some purified laccases ${ }^{26-30}$ in combination with other enzymes have been used to prepare bienzymatic electrodes for the determination of phenolic compounds ${ }^{26,27}$ and catecholamines. ${ }^{28-30}$ Nevertheless, only a biosensor for the determination of $\mathrm{O}_{2}$ in water using purified laccase from Pleurotus ostreatus has been described in the literature. ${ }^{31}$

In this paper, the construction of a biosensor based on carbon paste modified with crude extract, obtain by submerged culture of the fungi Pleurotus ostreatus, is proposed for the determination of the catecholamines adrenaline and dopamine in pharmaceutical formulations.

\section{Experimental}

\section{Reagents and solutions}

All reagents were of analytical-reagent grade and all solutions were prepared with water from a Millipore (Bedford, MA, USA) Milli-Q system (Model UV Plus UltraLow Organics Water).

A $0.05 \mathrm{~mol} \mathrm{~L}^{-1}$ 2,6-dimethoxyphenol (Sigma, St. Louis, MO, USA) in $0.1 \mathrm{~mol} \mathrm{~L}^{-1}$ phosphate buffer solution ( $\mathrm{pH}$ 3.5) was used for laccase activity determination.

Hydroquinone was purchased from Sigma (St. Louis, MO, USA) and a $5.0 \times 10^{-3} \mathrm{~mol} \mathrm{~L}^{-1}$ stock solution was prepared daily in $0.1 \mathrm{~mol} \mathrm{\textrm {L } ^ { - 1 }}$ phosphate buffer solution (pH 7.0). Reference solutions from $6.2 \times 10^{-5}$ to $8.9 \times 10^{-3}$ mol L-1 were prepared from stock solution by appropriate dilutions with the same buffer solution.

Catecholamine stock solutions at concentrations of 2.0 x $10^{-2} \mathrm{~mol} \mathrm{~L}^{-1}$ (Aldrich, Milwaukee, WI, USA) were prepared in $0.1 \mathrm{~mol} \mathrm{~L}^{-1}$ phosphate buffer solution and standardized by conventional methods. ${ }^{4,5}$ Adrenaline reference solutions from $6.0 \times 10^{-6}$ to $6.0 \times 10^{-4} \mathrm{~mol} \mathrm{~L}^{-1}$ and dopamine reference solutions from $6.0 \times 10^{-6}$ to $3.0 \times 10^{-4} \mathrm{~mol} \mathrm{~L}^{-1}$ were prepared from stock solutions in $0.1 \mathrm{~mol} \mathrm{~L}^{-1}$ phosphate buffer solutions at $\mathrm{pH} 7.0$ and $\mathrm{pH} 6.0$, respectively. In the construction of the biosensors an Acheson 38 graphite powder from Fisher and mineral oil from Sigma were used throughout.

\section{Instrumentation}

A Hewlett-Packard (Boise, ID, USA) Model 8452A UVvisible spectrophotometer with a quartz cell (optical path of $1.00 \mathrm{~cm}$ ) was used in the laccase activity and total protein determinations.

All electrochemical experiments were carried out in a $15 \mathrm{~mL}$ thermostated glass cell at $25^{\circ} \mathrm{C}$. A three-electrode assembly incorporating the biosensor as working electrode; an $\mathrm{Ag} / \mathrm{AgCl}\left(3.0 \mathrm{~mol} \mathrm{~L}^{-1} \mathrm{KCl}\right)$ reference and platinum auxiliary electrodes were used in all measurements. Differential Pulse Voltammetric measurements were performed with an EG\&G PAR, Model 273 A potentiostat/galvanostat with a CPIB-IIA/IIA interface and a PC equipped with data acquisition and treatment software was used to record the signal generated in the electrochemical cell.

\section{Crude laccase extract preparation}

Pleurotus ostreatus maintained on a potato agardextrose (PAD) ${ }^{32}$ medium was grown in submerged culture in Erlenmeyer flasks (1 L) containing $200 \mathrm{~mL}$ of Vogel $^{33}$ basal medium made of a minimal salts medium, $1 \% \mathrm{~m} / \mathrm{v}$ glucose and $0.2 \% \mathrm{~m} / \mathrm{v}$ yeast extract for 7 days at $28^{\circ} \mathrm{C}$, and shaken continuously at $180 \mathrm{rpm}$. Cell-free culture filtrates were obtained by centrifugation, then dialyzed against de-ionized water and freeze dried. 
The resulting supernatant was lyophilized at $4{ }^{\circ} \mathrm{C}$ and the crude extract utilized as the enzymatic source after laccase activity and total protein determinations.

\section{Laccase activity and total protein determinations}

The laccase activity of the crude extract was determined in triplicate by measurement of the absorbance at a wavelength of $468 \mathrm{~nm}\left(\varepsilon=1.0 \times 10^{4} \mathrm{~mol}^{-1} \mathrm{~L} \mathrm{~cm}^{-1}\right)$ of 2,6dimethoxyquinone produced in the reaction of $0.2 \mathrm{~mL}$ of enzyme solution ( $15 \mathrm{mg} \mathrm{mL}^{-1}$ crude extract), $2.7 \mathrm{~mL}$ of $0.05 \mathrm{~mol} \mathrm{~L}^{-1} 2,6$-dimethoxyphenol in $0.1 \mathrm{~mol} \mathrm{~L}^{-1}$ phosphate buffer solution ( $\mathrm{pH} 3.5$ ) at $30^{\circ} \mathrm{C}$, after five min of reaction. Laccase activity is expressed in $\mathrm{U}$ (one unit corresponds to the amount of enzyme which converts one $\mu \mathrm{mol}$ of 2,6dimethoxyphenol per minute at $\mathrm{pH} 3.5$ and $30{ }^{\circ} \mathrm{C}$ ).

Total protein concentration was determined in triplicate by the method of Hartree ${ }^{34}$ using bovine serum albumin as standard.

\section{Biosensor preparation}

The biosensor was initially prepared by adding and then homogenizing for $20 \mathrm{~min}$ in a mortar, $375 \mathrm{mg}$ of grafite powder and $23 \mathrm{mg}$ of crude laccase extract (1.2 units laccase/mg of carbon paste). This mixture was subsequently added to $110 \mathrm{mg}$ of Nujol and mixed in a mortar for at least $20 \mathrm{~min}$ to produce the final paste. A portion of each mixture (about $300 \mathrm{mg}$ ) was packed into the tip of a $1 \mathrm{~mL}$ insulin plastic syringe and a copper wire was inserted to obtain the external electric contact. Procedure for determination of catecholamines in
pharmaceutical samples

Differential pulse voltammetric (DPV) measurements were performed in unstirred and non-aerated $0.1 \mathrm{~mol} \mathrm{~L}^{-1}$ phosphate buffer solutions $(\mathrm{pH} 7.0$ for adrenaline and $\mathrm{pH} 6.0$ for dopamine), at $25^{\circ} \mathrm{C}$. The DPV voltammograms were obtained by scanning the potential from 50 to $-400 \mathrm{mV}$ (for adrenaline) and from 400 to $-50 \mathrm{mV}$ (for dopamine) at a scan rate of 30 $\mathrm{mV} \mathrm{s}^{-1}$ and potential pulse amplitude of $50 \mathrm{mV}$.

\section{Results and Discussion}

\section{Activity and total protein determinations}

As can be seen in the experimental section, laccase activity and total protein determinations were performed by spectrophotometry. The laccase activity obtained using 2,6-dimethoxyphenol as substract was $31.5 \mathrm{U} \mathrm{mL}^{-1}$ and the total protein was $2.01 \mathrm{mg} \mathrm{mL}^{-1}$. Owing to the high enzymatic activity and low total protein present, a high specific activity of $15.7 \mathrm{U}$ (mg of protein) $)^{-1}$ was obtained. A commercial laccase (Tienzyme Co) ${ }^{35}$ from the same fungi presents a specific activity of only $10.0 \mathrm{U}$ (mg of protein) $)^{-1}$.

\section{Principle of measurements}

Recently, the development of biosensors using novel biological materials as biocatalysts has received considerable attention for replacing isolated enzymes. ${ }^{11-13}$ The use of crude extract rather than isolated enzymes represents not only alternative and attractive analytical properties, but also simplicity, stability, longer lifetime, lower cost and reduced co-factor requirements. . $92,20,36^{2}$

Figure 1 shows a scheme of the enzymatic processes between catecholamine (adrenaline or dopamine) and laccase (PPO) of crude extract incorporated into a carbon paste electrode. Laccase catalyse the oxidation of adrenaline or dopamine to adrenoquinone or dopaminequinone in 1 minute. Then, the quinones produced at the electrode surface are eletrochemically reduced to the corresponding catecholamines at potentials of $-174 \mathrm{mV}$ (adrenoquinone) and $238 \mathrm{mV}$ (dopaminequinone) and the resulting cathodic currents correlate directly with the concentration of each catecholamine in the sample solution.

\section{Optimization of the biosensor response}

To obtain optimum response conditions for the biosensor based on carbon paste modified with a crude extract of Fungi Laccase, the effect of paste composition, initial stirring time, scan rate, potential pulse amplitude and $\mathrm{pH}$ (using hydroquinone, adrenaline and dopamine as substrates) was studied. Table 1 summarizes the range over which each variable was investigated and the optimal values found in those studies.

The effect of enzyme concentration from 0.29 to 1.8 units laccase/mg of carbon paste was investigated. The analytical signals (cathodic peak currents for $2.8 \times 10^{-4}$ mol L-1 hydroquinone in $0.1 \mathrm{~mol} \mathrm{~L}^{-1}$ phosphate buffer solution at $\mathrm{pH}$ 7.0) increased with increases in enzyme

Table 1. Optimization of biosensor parameters

\begin{tabular}{lcc}
\hline Biosensor parameter & Range studied & Optimal value \\
\hline Enzyme concentration & $0.29-1.8$ & 1.2 \\
(U/mg of carbon paste) & $30-150$ & 60 \\
Stirring time (s) & $10-40$ & 30 \\
Scan rate (mV s' $)$ & $10-60$ & 50 \\
Potential pulse amplitude $(\mathrm{mV})$ & $3.0-8.0$ & $7.0^{\mathrm{a}} ; 7.0^{\mathrm{b}}$ \\
$\mathrm{pH}$ & & and $6.0^{\mathrm{c}}$ \\
\hline
\end{tabular}

ahydroquinone; ${ }^{b}$ adrenaline and ${ }^{\mathrm{c}}$ dopamine. 
<smiles>NCCc1ccc(O)c(O)c1</smiles><smiles>CNCc1ccc(O)c(O)c1</smiles>

Adrenaline<smiles>NCCc1ccc(O)c(O)c1</smiles><smiles>CNCC(O)c1ccc(O)c(O)c1</smiles>

Adrenaline

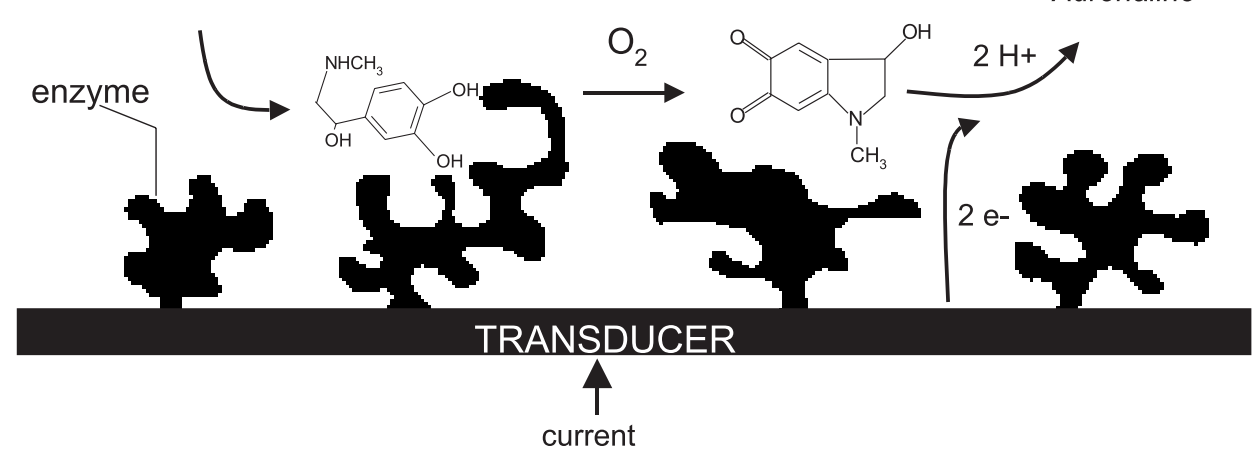

Figure 1. Schematic representation of the enzymatic process between catecholamines and laccase at the biosensor surface.

concentration, using up to 0.94 units laccase/mg of carbon paste and it was practically constant for higher enzyme concentrations. Thus, a concentration of 1.2 units laccase/ $\mathrm{mg}$ of carbon paste was used in all biosensors.

The effect of initial stirring time in an interval from 30 to $150 \mathrm{~s}$ on the biosensor response for $2.8 \times 10^{-4} \mathrm{~mol} \mathrm{~L}^{-1}$ hydroquinone in $0.1 \mathrm{~mol} \mathrm{~L}^{-1}$ phosphate buffer solution ( $\mathrm{pH}$ 7.0) was investigated to determine the best equilibrium time for the reaction. It was observed that $60 \mathrm{~s}$ was the best initial stirring to determining these substrates.

The effects of the pulse amplitudes (Figure 2) and potential scan rate (Figure 3) on the biosensor response for $2.8 \times 10^{-4} \mathrm{~mol} \mathrm{~L}^{-1}$ hydroquinone in $0.1 \mathrm{~mol} \mathrm{~L}^{-1}$ phosphate buffer solution $(\mathrm{pH}$ 7.0) were also investigated. A pulse amplitude of $50 \mathrm{mV}$ and a potential scan rate of $30 \mathrm{mV} \mathrm{s}^{-1}$ were selected, since with these experimental conditions, the highest analytical signal and very good differential pulse voltammogram profiles were obtained.

The effect of $\mathrm{pH}$ (Figure 4) from 3.0 to 8.0 for $2.8 \times 10^{-4}$ mol L-1 hydroquinone, $2.4 \times 10^{-4} \mathrm{~mol} \mathrm{~L}^{-1}$ adrenaline and $3.9 \times 10^{-4} \mathrm{~mol} \mathrm{~L}^{-1}$ dopamine solutions was investigated. The maximum current resulting from the enzyme catalysed reaction was observed at $\mathrm{pH} 7.0$ for hydroquinone and adrenaline and $\mathrm{pH} 6.0$ for the substrate dopamine. Therefore, a $\mathrm{pH}$ of 7.0 (hydroquinone and adrenaline) and 6.0 (dopamine) was used in further experiments.

\section{Reproducibility and lifetime studies}

The relative standard deviation was smaller than $1.8 \%$

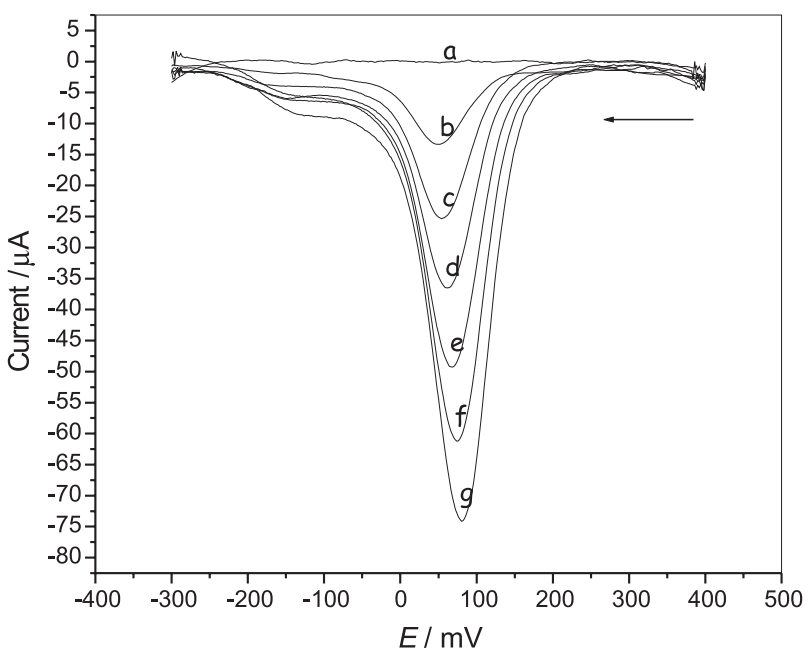

Figure 2. Differential pulse voltammograms at scan rates of $30 \mathrm{mV}$ $\mathrm{s}^{-1}$ and pulse amplitude of $40 \mathrm{mV}$ for (a) $0.1 \mathrm{~mol} \mathrm{~L}^{-1}$ phosphate buffer solution ( $\mathrm{pH}$ 7.0) (blank) and $2.8 \times 10^{-4}$ hydroquinone in 0.1 mol L-1 phosphate buffer solution $(\mathrm{pH} 7.0)$ at the following amplitude pulses: (b) $10 \mathrm{mV}$; (c) $20 \mathrm{mV}$; (d) $30 \mathrm{mV}$; (e) $40 \mathrm{mV}$; (f) $50 \mathrm{mV}$ and $(\mathrm{g}) 60 \mathrm{mV}$.

for $2.8 \times 10^{-4} \mathrm{~mol} \mathrm{~L}^{-1}$ hydroquinone solution at $\mathrm{pH} 7.0$ $(n=10)$. The reproducibility of three biosensors prepared with the same composition (375 mg of grafite powder $(73.8 \% \mathrm{~m} / \mathrm{m}), 23 \mathrm{mg}$ of crude laccase extract $(1.2$ units laccase $/ \mathrm{mg}$ of carbon paste) $(4.5 \% \mathrm{~m} / \mathrm{m})$ and $110 \mathrm{mg}$ of Nujol $(21.7 \% \mathrm{~m} / \mathrm{m})$ ) showed only a slight variation $(9.3 \%)$ of the analytical curve slope.

After 14 days (over 240 determinations) the response of the biosensor was $75 \%$ of the initial response, 


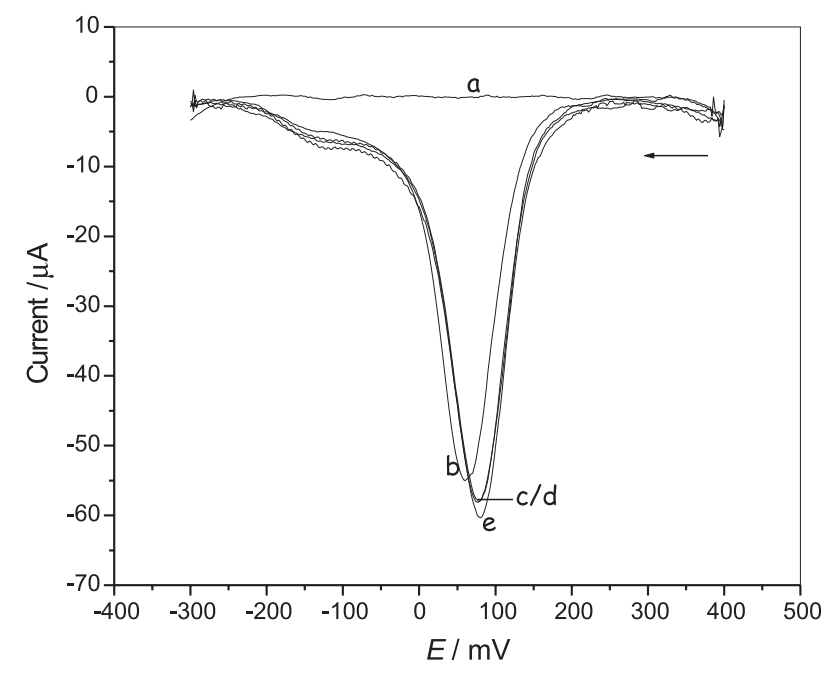

Figure 3. Differential pulse voltammograms at pulse amplitude of $50 \mathrm{mV}$ and scan rate of $30 \mathrm{mV} \mathrm{s}^{-1}$ for (a) $0.1 \mathrm{~mol} \mathrm{~L}^{-1}$ phosphate buffer solution ( $\mathrm{pH} 7.0$ ) (blank) and $2.8 \times 10^{-4}$ hydroquinone in 0.1 mol $\mathrm{L}^{1}$ phosphate buffer solution $(\mathrm{pH} 7.0)$ at pulse amplitude of 50 $\mathrm{mV}$ and the following scan rates: (b) $10 \mathrm{mV} \mathrm{s}^{-1}$; (c) $20 \mathrm{mV} \mathrm{s}^{-1}$; (d) 30 $\mathrm{mV} \mathrm{s}^{-1}$; (e) $35 \mathrm{mV} \mathrm{s}^{-1}$ and $40 \mathrm{mV} \mathrm{s}^{-1}$ at pulse amplitude of $50 \mathrm{mV}$.

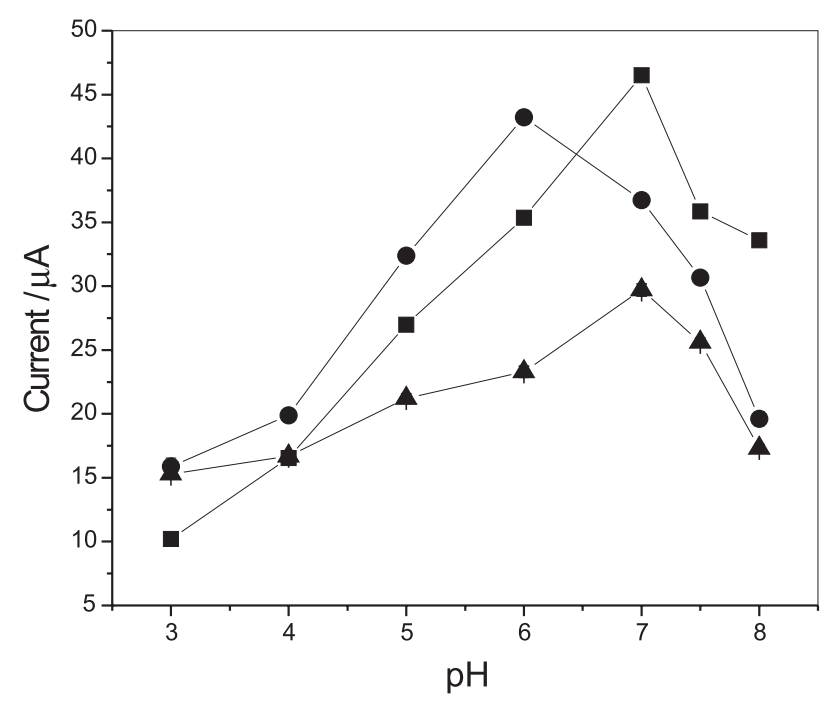

Figure 4. Effect of $\mathrm{pH}$ on the biosensor response. $\mathbf{\square}: 2.8 \times 10^{-4} \mathrm{~mol}$ $\mathrm{L}^{-1}$ hydroquinone solution; $\boldsymbol{\Delta}: 2.4 \times 10^{-4} \mathrm{~mol} \mathrm{~L}^{-1}$ adrenaline solution and $\bullet: 3.9 \times 10^{-4} \mathrm{~mol} \mathrm{~L}^{-1}$ dopamine solution at $25^{\circ} \mathrm{C}$.

confirming, as expected, the high stability of the crude extract of the fungi laccase.

\section{Biosensor applications}

Using the optimized experimental conditions (Table 1), DPV measurements with the proposed biosensor in a recovery study and also in the determination of adrenaline and dopamine in pharmaceutical formulations were carried out.
The effect of excipient substances frequently found with adrenaline and dopamine in pharmaceutical formulations, such as lactose, glucose, sodium chloride, sodium sulfite and phosphate, was evaluated using the proposed procedure. The ratios of the concentrations of adrenaline and dopamine to the excipient substances were fixed at $0.1,1.0$ and 10.0. Of the compounds investigated, only sodium sulfite causes significant interference on biosensor response. In order to eliminate this interference, prior sample treatment with a formaldehyde solution ${ }^{15}$ in the [formaldehyde]/[sulfite] ratio $\geq 2$ was carried out. Recoveries varying from 97.3 to $101 \%$ of adrenaline and 95.8 to $102 \%$ of dopamine from a pharmaceutical product were obtained using the modified carbon paste electrode (Table 2). In this study, 33.0, 65.0, and $107.0 \mathrm{mg} \mathrm{L}^{-1}$ of adrenaline solutions and 25.0, 49.0, and $62.0 \mathrm{mg} \mathrm{L}^{-1}$ of dopamine solutions were added to the samples and the cathodic current peak was obtained. The recovery results obtained suggest the absence of a matrix effect in those determinations.

Table 2. Results of the addition-recovery experiment using adrenaline or dopamine with three different standard concentrations

\begin{tabular}{lccc}
\hline \multirow{3}{*}{ Sample } & \multicolumn{3}{c}{$\begin{array}{c}\text { Adrenaline or dopamine } \\
\left(\mathrm{mg} \mathrm{L}^{-1}\right)^{\mathrm{a}}\end{array}$} \\
& Added & Found & Recovery (\%) \\
\hline Adrenaline (Ariston) & 33.0 & $32.1 \pm 0.8$ & 97.3 \\
& 65.0 & $64.5 \pm 0.9$ & 99.2 \\
& 107.0 & $108.1 \pm 0.6$ & 101 \\
& & & \\
Dopamine (Ariston) & 25.0 & $23.9 \pm 0.9$ & 95.8 \\
& 49.0 & $50.0 \pm 0.6$ & 102 \\
& 62.0 & $61.7 \pm 0.3$ & 99.5 \\
\hline
\end{tabular}

${ }^{\mathrm{a}} n=3$.

Figures 5 and 6 present the differential-pulse voltammograms using the proposed biosensor in the determination of adrenaline and dopamine in pharmaceutical formulations. The analytical curve obtained was linear from $6.0 \times 10^{-5}$ to $7.0 \times 10^{-4} \mathrm{~mol} \mathrm{~L}^{-1}$ of adrenaline (Icp $=0.17+42277$ [adrenaline] $\left.\mathrm{mol} \mathrm{L}^{-1}\right) ; \mathrm{r}=0.9989$, and from $7.0 \times 10^{-5}$ to $4.0 \times 10^{-4} \mathrm{~mol} \mathrm{~L}^{-1}$ of dopamine (Icp $=0.96$ + 63791[dopamine] mol L-1); $\mathrm{r}=0.9978$, with a detection limit (three times the blank standard deviation/slope) of $7.9 \times 10^{-6} \mathrm{~mol} \mathrm{~L}^{-1}$ for adrenaline and $9.8 \times 10^{-6} \mathrm{~mol} \mathrm{~L}^{-1}$ for dopamine. Table 3 presents the results obtained for two commercial samples using the pharmacopeial spectrophotometric procedure ${ }^{37}$ and the proposed biosensor. Applying a paired t-test to the results obtained by the two procedures, it was found that all results are in agreement at the $95 \%$ confidence level and within an acceptable range of error. 


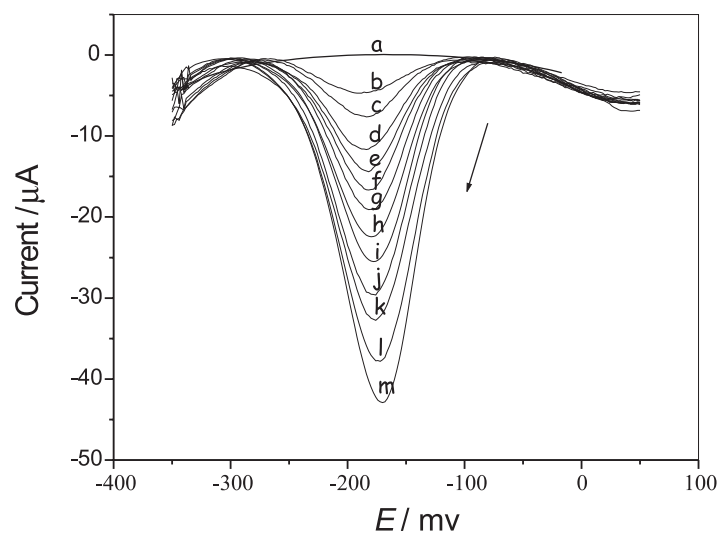

Figure 5. Differential pulse voltammograms (adrenaline analytical curve) (a) $0.1 \mathrm{~mol} \mathrm{~L}^{-1}$ phosphate buffer solution ( $\mathrm{pH}$ 7.0) (blank) and adrenaline solutions at the following concentrations: (b) $0.6 \mathrm{x}$ $10^{-4}$; (c) $1.2 \times 10^{-4}$; (d) $1.8 \times 10^{-4}$; (e) $2.4 \times 10^{-4}$; (f) $3.0 \times 10^{-4}$; (g) 3.6 x $10^{-4}$; (h) $4.7 \times 10^{-4}$;(i) $5.8 \times 10^{-4}$; (j) $6.9 \times 10^{-4}$; (k) $8.0 \times 10^{-4}$; (1) 9.1 x $10^{-4}$ and $(\mathrm{m}) 10.1 \times 10^{-4} \mathrm{~mol} \mathrm{~L}^{-1}$ at scan rate of $30 \mathrm{mV} \mathrm{s}^{-1}$, pulse amplitude of $50 \mathrm{mV}$ and $25{ }^{\circ} \mathrm{C}$.

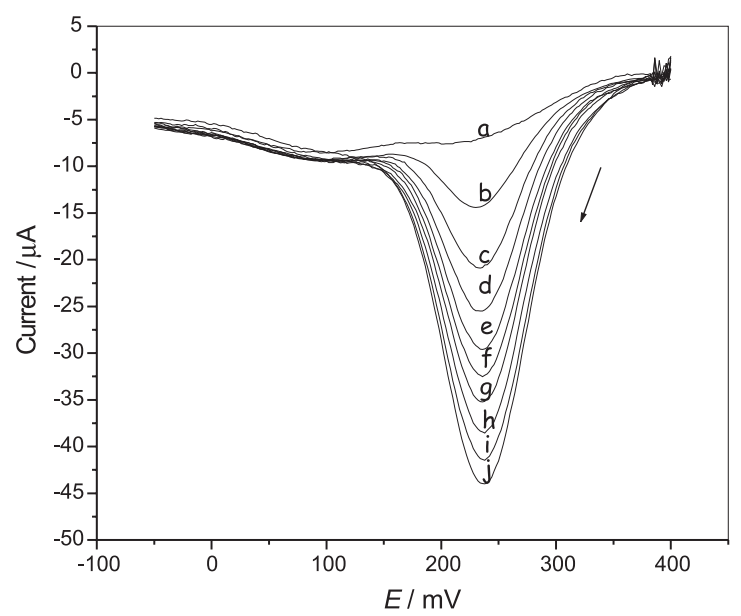

Figure 6. Differential pulse voltammograms (dopamine analytical curve) (a) $0.1 \mathrm{~mol} \mathrm{~L}^{-1}$ phosphate buffer solution ( $\mathrm{pH}$ 6.0) and dopamine solutions at the following concentrations: (b) $0.7 \times 10^{-4}$; (c) 1.3 x $10^{-4}$; (d) $2.0 \times 10^{-4}$; (e) $2.6 \times 10^{-4}$; (f) $3.3 \times 10^{-4}$; (g) $3.9 \times 10^{-4}$; (h) $4.5 \times 10^{-4}$; (i) $5.1 \times 10^{-4}$ and (j) $5.8 \times 10^{-4} \mathrm{~mol} \mathrm{~L}^{-1}$, at scan rate of 30 $\mathrm{mV} \mathrm{s}^{-1}$, pulse amplitude of $50 \mathrm{mV}$ and $25^{\circ} \mathrm{C}$.

Table 3. Determination of adrenaline and dopamine in pharmaceutical formulations using the pharmacopeia ${ }^{37}$ and the biosensor procedures

\begin{tabular}{|c|c|c|c|}
\hline Sample & $\begin{array}{r}\text { Pharmacopeia } \\
\text { (mg }\end{array}$ & $\begin{array}{l}\text { Biosensor } \\
-1 \text { ) }\end{array}$ & $\begin{array}{l}\text { Relative } \\
\text { error (\%) }\end{array}$ \\
\hline \multicolumn{4}{|c|}{ Adrenaline } \\
\hline A & $1.08 \pm 0.04$ & $1.04 \pm 0.03$ & -3.7 \\
\hline B & $0.99 \pm 0.03$ & $1.01 \pm 0.02$ & +2.0 \\
\hline \multicolumn{4}{|c|}{ Dopamine } \\
\hline A & $4.96 \pm 0.06$ & $4.82 \pm 0.04$ & -2.8 \\
\hline B & $5.02 \pm 0.03$ & $4.97 \pm 0.02$ & -1.0 \\
\hline
\end{tabular}

\section{Conclusions}

A biosensor based on carbon paste modified with a crude extract of laccase (obtained from the fungi Pleurotus ostreatus) is reliable, simple, rapid to prepare, of low cost, sensitive, precise and accurate. These characteristics make this biosensor an attractive alternative to the procedures presently for pharmaceutical and clinical applications.

\section{Acknowledgments}

The authors would like to thank the Fundação de Amparo à Pesquisa do Estado de São Paulo (FAPESP), Coordenacão de Pessoal de Nível Superior (CAPES) and CNPq (Conselho Nacional de Desenvolvimento Científico e Tecnológico), for financial support and the $11^{\circ}$ ENQA Organizing Committee.

\section{References}

1. Szeponik, J.; Möller, B.; Pfeiffer, D.; Lisdat F.; Wollenberger, U.; Makower, A.; Scheller, F.W.; Biosensors Bioeletronics 1997, $12,947$.

2. Hoffman, B.B.; Lefkowitz, R.J. In The Pharmacological Basis of Therapeutics; Gilman A. G. ed. , $9^{\text {th }}$ ed., McGraw-Hill: New York, 1996, pp. 211-219.

3. Pesce, A.J.; Kaplan L. A. In Methods in Clinical Chemistry; Bircher, S. ed., The C.V. Mosboy Company: St Louis, MO, 1987, pp. 944-963.

4. Fatibello-Filho, O.; Vieira, I.C.; Analyst 1997, 122, 345.

5. Vieira, I. C.; Fatibello-Filho, O.; Talanta 1998, 46, 559.

6. Adams, R.N.; Anal. Chem. 1976, 48, 1128A.

7. Matysik, F.M.; Nagy, G.; Purgor, E.; Anal. Chim. Acta 1992, 264, 177.

8. Brun, A.; Rosset, R.; J. Electroanal. Chem. 1974, 49, 287.

9. Hafizi, S.; Kauk, Z. L.; Stanford, J. A.; J. Electroanal Chem. 1990, 283, 125.

10. Hall, G.F.; Best, D. J.; Turner, A.P.F.; Anal. Chim. Acta 1988, $213,113$.

11. Cosnier, S.; Innocent, C. J.; Electroanal. Chem. 1992, 328, 361.

12. Kulys, J.; Schimid, R.O.; Anal. Lett. 1990, 23, 589.

13. Wang, J.; Ciszewski, A.; Naser, N.; Electroanalysis 1992, 4, 777.

14. Rechnitz, G. A.; Science 1981, 214, 287.

15. Vieira, I. C.; Fatibello-Filho, O.; Talanta 2000, 52, 681.

16. Fatibello-Filho, O.; Vieira, I. C.; Fresenius' J. Anal. Chem. 2000, 368, 338.

17. Fatibello-Filho, O.; Vieira, I C.; J. Braz. Chem. Soc. 2000, 11, 412.

19. Kalcher, K.; Kauffmann, J. M.; Wang, J.; Svancara, I.; Vytras, K.; Neuhold, C.; Yang, Z.; Electroanalysis 1995, 7, 5. 
20. Kissinger, P. T.; Heineman, W. R.; Laboratory Techniques in Electroanalytical Chemistry, $2^{\text {nd }}$ ed., Marcel Dekker: New York, 1996.

21. Yaropolov, A. I.; Skorobolat'ko, O. V.; Vartanov, S. S.; Varfolomery, S. O.; Appl. Biochem. Biotechnol. 1994, 49.257.

22. Cullen, D.; J. Biotechnol. 1997, 53, 273.

23. Ong, E.; Pollock, W. B. R.; Smith, M.; Gene 1997, 196, 113.

24. Collis, P. J.; Dowson, A. D. W.; Appl. Environm. Microbiol. 1997, 63, 3444 .

25. Hatamoto, O.; Sekine, H.; Nakano, E.; Abe, K.; Biosci. Biotechnol. Biochem. 1999, 63, 58.

26. Freire R. S.; Thongngamdee, S.; Duran N.; Wang J.; Kubota, L. T.; Analyst 2002, 127, 258.

27. Zouari, N.; Romette, J. T.; Thomas, D.; Biotechnology Techniques 1994, 8, 503.

28. Bier, F. F.; EhrentreichForster, E.; Makower, A., Scheller F. W.; Anal. Chim. Acta 1996, 328, 27.

29. Ghindilis, A. L.; Makower, A.; Bauer, C. G.; Bier, F. F.; Scheller, F. W.; Anal. Chim. Acta 1995, 304, 25.
30. Bier, F. F.; EhrentreichForster, E.; Bauer, C. G.; Scheller F. W.; Fresenius' J. Anal. Chem. 1996, 354, 861

31. Barton, S. C.; Pickard, M.; Vazquez-Duhalt, R.; Heller, A.; Biosensors Bioeletronics 2002, 17, 1071.

32. Leite, O. D.; Endo, A. S.; Felisbino, M.P.; Obara-Doi, S.M.; Fonseca, R.C.; Barbosa, A. M.; Third Latin American Biodegradation \& Biodeterioration Symposium, Book of Abstracts, Florianópolis, Brazil, September 1998.

33. Vogel, H.; J. Genet. Bull. 1956, 13,42.

34. Hartree, E. S.; Anal. Biochem. 1972, 48, 422.

35. Tienzyme Company, http://TIENZYME.com, accessed in July 2002.

36. Gorton, L.; Electroanalysis 1995, 7, 23.

37. United States Pharmacopeia National Formulary XXXIII, US Pharmacopeial Convention, Rockville, MD, 1995.

Received: October 19, 2002 Published on the web: March 28, 2003

FAPESP helped in meeting the publication costs of this article. 